\title{
Reflexive and project-based forms of psychological and anthropological practice of developing creativity in children
}

\author{
Natalia B. Kovaleva ${ }^{1^{*}}$ and Anastasiya I. D’yakonova ${ }^{2}$ \\ ${ }^{1}$ Moscow Pedagogical University, Institute of Childhood Department of Psychological Anthropology, \\ Moscow, Russia \\ ${ }^{2}$ School 1329, Moscow, Russia
}

\begin{abstract}
The article deals with the possibilities of reflexive and projectbased forms of anthropological practice which make it possible to create an environment for the development of the individual's creative orientation and creativity in the context of the modern media environment. The authors focus on the design and testing of innovative technologies in the field of humanities in the rapidly changing conditions of children and adolescents who are growing up in the digital environment of the 21 st century. The specific features of the media environment in terms of determining the anthropological imperative of the educational prototype are examined. Based on theoretical and practical developments, the principles of deploying such technologies in the format of educational anthropological practices are demonstrated. The authors substantiate the resource potential of co-creative forms of psychological and pedagogical anthropological practice based on the original reflexive-positional approach to the personal development of children in primary and secondary school. The emphasis is on the presentation of two reflexive-positional technologies that have proven their practical efficiency/ These technologies are based on the principles of project reflection, namely, plot and activity-based game and mediahermeneutics. The principles of creating a transformative sociocultural educational environment that initiates the development of giftedness and creativity of children and adolescents in mediahermeneutics technologies are described in detail. The authors provide the results of a comprehensive study of the personality and creativity development among children and adolescents based on reflexive and project-based technologies of psychological and pedagogical anthropological practices to identify the relationship between the personal and creative development of children and adolescents participating in programs built using mediahermeneutics. The discussion of the results allows one to conclude that project-based and reflexive forms of anthropological practice, when properly organized, in particular using the principles of mediahermeneutics, contribute to the development of spiritual value orientations, creative focus, cognitive and aesthetic motivation and create the environment for the manifestation of adolescent giftedness.
\end{abstract}

\footnotetext{
* Corresponding author: nkovaig@mail.ru
} 
Keywords: reflexive-positional approach, anthropological practice, worldview, positionality, mediahermeneutics.

\section{Introduction}

The relevance of the development of mediahermeneutic technologies as an area for developing giftedness is determined by the urgent issues of society associated with the anthropological crisis of personality development. The studies by various authors contain the characteristics of how the younger generation is growing up in a new situation of socialization [1-7], accompanied by the insufficient formation of the spiritual and moral sphere, value orientations, worldview and, consequently, a decreased ability to build their own development programs and life-long projects and creative self-actualization based on cultural heritage. We believe that the reasons for such a decrease include: a) the influence of the modern media environment which forms the stereotyped thinking, pseudo understanding and culture of random opinions, and b) the insufficient development of the culture of understanding text and project forms of reflection.

\section{Methods}

Mediahermeneutics [8] as a new technology in the field of humanities meets the educational challenges of the modern era. The reflexive-positional approach is one of the most productive approaches to solving these problems in various forms of educational anthropological practice. One of the technological principles is the creation of a common synergistic and project-based discursive environment to expand the horizons of understanding based on attentive listening to the utterances by the participants, the author, characters and the text.

Important characteristics of the environment of communication and understanding of texts in the reflexive and project-based forms of anthropological practices are:

1.Dialogicality. Dialogue is at the heart of the culture of the entire 20th century and is particularly important in the age of high-speed communications. The understanding of the dialogue determines the development of productive thinking and ensures the efficiency of working together.

2. Metaphoricity. Metaphors are crucial components of the language. The ability to create metaphors is at the core of creative thinking. Metaphorical understanding arises based on an allegorical description of phenomena and objects, in the absence of adequate terminology for working with them, and ensures the emergence of new horizons and meanings.

3. Humor. Humor in modern culture is becoming increasingly more significant as a modern cultural value, an attribute of the developed consciousness of a creative person, as a way of building relationships and gaining a higher status in a group, as a form of the comical.

4. Projectivity. The image of the future is something that does not yet exist, that has not yet been cognized but is important both for the individual and for society. This understanding is based on cultural heritage and underlies any creative act.

5. Hypertextuality and nonlinearity. Hypertext belongs to the non-linear cultural forms and is characterized by symbolism, simulacrativity and reflexivity. Understanding hypertext is at the core of modern forms of thinking. Hypertextuality is both one of the essential characteristics of modern literature and a way of presenting knowledge.

6.Paradoxicality. The paradoxicality of thinking has always been typical of talented people capable of generating new powerful ideas and promoting them in society. Paradoxicality is an important characteristic of thinking and language that provides depth, expressiveness and wit. 
One should note that the participants in such communication are not only peers, but also teachers, moderators, experts, authors, and the texts included in the communication situation. An important point is also the introduction of some intrigue or conflict inside the script, which creates motivation for the participants in the educational situation to manifest their positions.

The following schematization of the stages of work can be proposed:

1. Identifying the main content blocks of the text and its normative analysis. 2. Identifying the main subjects of the text and their attitude to the main event. 3. Characteristics of the compositional features of the piece (the growing significance of the event for society, high informational capacity of the text, independent video sequence that reveals the content of the text, high speed of unfolding events, fixed alternative and multiple opinions, elements of journalistic investigation). 4. Creation of intertextual and hypertextual links and schematization of discourse. 5. Formulation of problematizing questions that initiate the contemplation, questioning, taking them beyond the bounds of the obvious. 6 . Reconstruction of the author's position and determination of the place of this issue in culture. 7. Inclusion of forms of creative reflection (sketches, drawings, dances, etc.).

These technologies have been tested and have shown their efficiency in a variety of formats and environments: in children's summer camp programs, communicativehermeneutic and plot and activity-based trainings and youth forums, as well as in basic education. We carried out a comprehensive study of the development of the personality and creativity of children and adolescents based on reflexive and project-based technologies for transforming the socio-cultural educational environment to identify the relationship between the personal and creative development of children and adolescents participating in programs built around mediahermeneutics $[2,8]$.

\section{Results}

1. Research into the influence of external motivation on the productivity of working together, the worldview, the position and orientation of older preschoolers. The analysis of the products of children aged 6-7 years working together carried out based on the reflexivepositional technique of artistic stories and their illustrations using content analysis made it possible to identify qualitative differences in the children's drawings, orientation and worldview. It was discovered that a group of children, working in the context of competitive motivation, tried to complete the task with maximum speed, stereotypically, schematically. In groups that were given creative motivation from the outside, the participants tried to join forces, and the story turned out to be innovative with the use of figurative details and vivid content. Thus, it can be said that external motivation contributes to the manifestation of creativity when it enhances cognitive motives and not the motives of achievement.

2. The study of the influence of external motivation on the worldview, the position, orientation of younger schoolchildren and the productivity of working together creatively confirmed the results of the first study. The characteristics of the products of co-creation which were stories created based on the tales of Baron Munchausen differed depending on the external motivation set for the group. In groups that were given creative external motivation, the stories turned out to be comprehensive, with elements of adventure included heroic actions in the style of the Baron himself, that is, had signs of artistry. It is also important that while working together, the children correlated their values, worldview characteristics which made it possible to take a step in their development and began to serve as a common basis for the story being composed. Groups with competitive motivation showed a focus on quick functional results and offered superficial solutions.

3. The study of the relationship between worldview, value orientations and the orientation and creative productivity of adolescent students. A comparative analysis of the value orientations and creative orientation of adolescents in Moscow schools and participants in 
development programs designed in the technologies of the reflexive-positional approach in the Irkutsk region revealed that 1) consumer values prevail among students in years 6-7 in Moscow schools, which make up $60 \%$. The rest of the values are mild and spiritual values have a particularly low result $(4 \%)(t=2.06$ according to the Student's $t$-test at $\mathrm{p}=0.05)$. Since this is a pilot study that included only 100 people, it is difficult to talk about Muscovites as a whole, but for this group it is necessary to record that adolescents, "growing" into the culture, are guided, first of all, by consumer values - motivational-need and value-based semantic areas are dominated by the desire to have, to possess, and not to be or develop. At least, a quick survey without special training reveals this orientation. 2) In the Irkutsk Region, adolescents who participate in the experimental developmental program show predominantly spiritual (21\%), aesthetic and instrumental $(26 \%)$ values $(t=2.86$ according to the Student's t-test at $\mathrm{p}=0.05)$. 3) During the developmental experiment at the International English School, in the process of writing a story together as a sequel to the adventures of Baron Munchausen, the following changes occurred in the system of value orientations (tabular value of the F-distribution is 1.8894; significance level is a $=0.05$ : social values $(42 \%)$ remained in the same position, consumer values slightly increased from $22 \%$ to $27 \%$, and there was a significant increase in spiritual values from $15 \%$ to $33 \%$. The answers confirm that working together creatively, with proper organization, in particular the use of reflexivepositional technologies, contribute to the development of spiritual value orientations, creative orientation, cognitive and aesthetic motivation and create the environment for the manifestation of adolescent giftedness (based on the material of artistic creativity).

\section{Discussion}

Therefore, one can see that the hypothesis of the relationship between motivational, valuesemantic spheres and creative productivity has been confirmed. The process of working together creatively organized based on the principles of project-based forms of positional reflection and mediahermeneutics, allows one to reveal the creative potential of children and adolescents, and also contributes to the formation of a creative orientation and wide socialization of children and adolescents. The results correlate with the provisions of the theory of creativity about the importance of artistic creativity and research $[9,10]$, research into the relationship of personal and cognitive factors of development and giftedness [4, 11$15]$ and with the provisions of reflexive psychology $[16,17]$ and others.

\section{Conclusion}

Analysis of the modern educational prototype, models and strategies for the development of society, according to leading psychologists, cultural studies teachers and other scholars, allows one to summarize that people are rapidly approaching a situation that unambiguously requires humans to be "human", that is, first of all, abilities in the context of uncertainty of huge information flows, simulacrative processes, including a fake culture of presenting information, see problems, self-define in relation to them and solve them creatively, transforming the situation and oneself. Mediahermeneutics as an innovative technology in the field of humanities meets a civilizational challenge, makes it possible to create an environment for the creative development of children and youth through the development of a culture of understanding, requires constant professional growth from psychologists and teachers, scaling the results and is a promising form of psychological and anthropological practice in the development of the child and adolescent giftedness. 


\section{References}

1. A.A. Verbitskii, Professionalnoe Obrazovanie. Stolitsa, 7, 10-13 (2016)

2. N.B. Kovaleva, N.V. Davydova, A.I. Dyakonova Razvitie lichnosti i sposobnostei uchashchikhsya srednei shkoly. Praktikum po psikhologo-pedagogicheskomu stsenirovaniyu razvivayushchikh zanyatii v refleksivno-pozitsionnykh i mediagermenevticheskikh tekhnologiyakh. [Personality development and development of abilities in middleschoolers. Workshop on psychological and pedagogical staging of developmental classes in reflexive-positional and mediahermeneutic technologies] (MODI, Moscow, 2018)

3. S. Gehlert, K.L. Hall, L.A. Palinkas, Journal of the Society for Social Work and Research, 8(1), 119-136 (2017). https://doi.org/10.1086/690659

4. K. Darvishzadeh, Z.D. Bozorgi, Asian Social Science, 12(3), 170-176 (2016). https://doi.org/10.5539/ass.v12n3p170

5. S. Kustiah, D.D. Gufran, International Education Studies, 8(10), 107-113 (2015). https://doi.org/10.5539/ies.v8n10p107

6. L. Maheady, K. Magiera, R. Simmons, Rural Special Education Quarterly, 35(2), 33 (2016)

7. I.D. Mitina, B.S. Vasyakin et al., Modern Journal of Language Teaching Methods, 7(12), 275-285 (2017)

8. N.B. Kovaleva, Psikhologicheskaya Nauka I Obrazovanie, 9(4), 64-71 (2014)

9. D.B. Bogoyavlenskaya (Ed.), Psikhologiya tvorchestva i odarennosti [Psychology of Creativity and Giftedness], in Materialy vserossiiskoi nauchno-prakticheskoi konferentsii [Proceedings of the All-Russian Scientific and Practical Conference], 445451 (MPGU Publishing, Moscow, 2018)

10. L.I. Larionova, A. I. Savenkov (Eds.), Psikhologiya odarennosti i tvorchestva [The psychology of giftedness and creativity] (Nestor-Istoriya, Saint Petersburg, 2017)

11. B. Dahlin, Rudolf Steiner: The Relevance of Waldorf Education (Springer International Publishing, New York, 2017). https://doi.org/10.1007/978-3-319-58907-7

12. R.N. Dino. Psychology of Aesthetics, Creativity, and the Arts, 9(2), 139-146 (2015). https://doi.org/10.1037/aca0000015.

13. E. Midouhas, E. Flouri, Population, Space and Place, 21(2), 157-170 (2015). https://doi.org/10.1002/psp.1815

14. M. Tang, C.H. Werner, Thinking Skills and Creativity, 24, 268-278 (2017). https://doi.org/10.1016/j.tsc.2017.04.001.

15. Y. Wang, L. Wang, Personality and Individual Differences, 99, 184-189 (2016). https://doi.org/10.1016/j.paid.2016.04.086

16. N.G. Alekseev, Razvitie Lichnosti, 2, 85-102 (2002)

17. I.N. Semenov, N.B. Kovaleva, S.Yu. Stepanov, Mir Psikhologii, 4, 273-288 (2019) 